\title{
Synthesis Docking Studies, Characterization and Anti-tubercular Activity of Ofloxacin Containing Thiazolidinone Derivatives
}

\author{
Ramakrishna Chintakunta ${ }^{1, *}$, GV Subbareddy ${ }^{2}$ \\ 'Department of Pharmaceutical Sciences, JNTUA University, Anantapuramu, Andhra Pradesh, INDIA. \\ 2Department of Chemistry, JNTUA college of engineering, Pulivendula, Andhra Pradesh, INDIA.
}

\begin{abstract}
Background: Ofloxacin is a fluoroquinolone antibiotic very useful in the treatment of several bacterial infections. The Thiazolidinone ring system represents a privileged structure in drug discovery. multi-drug-resistant tuberculosis bacteria infects many people worldwide and the disease kills 1.8 million people annually, so a combination of ofloxacin-thiazolidinone gives a great promise for future potential antitubercular drugs. Methods: Ofloxacin is treated with hydrazine hydrate results in the form of ofloxacin hydrazides. These hydrazides were treated with various aromatic aldehydes form ofloxacin containing Schiff bases. These compounds are treated with thioglycolic acid in presence of zinc chloride, DMF as solvent forms the ofloxacin containing thiazolidinone derivatives. These derivatives (T1, T2, T3, T4, T5, T6) were purified using Ethanol by recrystallization procedure. Chimera software is used for protein stabilization. The protein 5BS8 was downloaded from PDB. Results: these derivatives are characterized byTLC, melting point, solubility and Spectroscopic methods like FT-IR, ${ }^{1} \mathrm{H}-\mathrm{NMR}$ and HRMS. Predicted in silico studies using Autodock vina, which is academic free version software and performed antitubercular action of synthesized
\end{abstract}

compounds using standard drugs. The concentrations were prepared $(0.8,1.6,3.12,6.25,12.5,25,50,100 \mu \mathrm{g} / \mathrm{ml})$ and performed antitubercular Assay using the Microplate Alamar Blue Assay method (MABA method). Docking studies were done using autodock vina free software. Conclusion: MIC values reveal that all the synthesized derivatives show the activity in the concentration $1.6 \mu \mathrm{g} / \mathrm{ml}$ compared to standard drugs. the docking studies results that all compounds from T1-T6 showed good binding energies above the standard, the results reveal that these compounds are potent antitubercular agents.

Key words: Ofloxacin, Thiazolidinone, Antitubercular activity, Docking studies, MABA method, Autodock Vina.

Correspondence

Mr. Ramakrishna Chintakunta,

Research Scholar, JNTUA, Anantapur-515001, Andhra Pradesh, INDIA.

Email id: rama0813@gmail.com

DOI: 10.5530/jyp.2022.14.15

\section{INTRODUCTION}

Ofloxacin is a new second-generation fluoroquinolone structurally related to nalidixic acid. ${ }^{1}$ Fluoroquinolones were used widely for the treatment of mild to moderate bacterial infections. But that has been replaced by more potent and less toxic fluoroquinolones and ofloxacin is used worldwide topically as eye and ear drops. ${ }^{2}$ Ofloxacin is an antibiotic very useful for the treatment of several bacterial infections. ${ }^{3}$ When taken by oral or intravenous into a vein. These include urinary tract infections pneumonia, cellulitis, prostatitis, plague, infectious diarrhoea, along with other medications. ${ }^{4}$ Including treating multi-drug-resistant tuberculosis. It is also used for otitis media as ear drops and superficial infections. ${ }^{5}$ Ofloxacin was available as a generic drug USFDA approved drug. It was the most commonly prescribed drug in India and other countries, using more than one million prescriptions. ${ }^{6}$ Ofloxacin is active against both grams negative and gram-positive bacteria. ${ }^{7}$ It has a mechanism of action by inhibiting two bacterial enzymes like type II topoisomerases or DNA gyrase and topoisomerase IV. ${ }^{8}$

Tuberculosis is caused due to mycobacterium tuberculosis. This infection is transmitted through the inhalation of droplets. Tuberculosis is a highly contagious disease, In the active stage of the disease and can infect one person to other through inhalation of few as ten mycobacterium tuberculosis. $^{9}$ After inhalation, these tubercular bacteria are captured by alveolar macrophages. Still, they can evade the host's immune system for a long time, at which point they can reactivate become virulent forms under immune-compromised conditions of the host. ${ }^{10}$ TB bacteria can attack other parts of the body, such as the kidney, spine and brain. If properly not given treatment, TB disease can be fatal. ${ }^{11}$ The newly infected person becomes infectious enough to transmit the disease to others. ${ }^{12}$ The tests like chest $\mathrm{x}$-ray and sputum are needed to see whether the person has TB disease. ${ }^{13}$ Tuberculosis may infect mostly the lungs so-called pulmonary tuberculosis. ${ }^{14}$ Pulmonary TB may coexist along with extrapulmonary TB. ${ }^{15}$ other signs and symptoms include fever, sweat at night, chills, fatigue, loss of appetite, loss of weight, ${ }^{16}$ The common use of rifabutin instead of rifamycin in HIV-positive infective people with tuberculosis is of unclear benefit $2007 .{ }^{17}$ Scientists have determined by the three-dimensional structure of the target of the firstline anti-tubercular drugs. ${ }^{18}$ They have also discovered new potential anti-tuberculosis drugs that kill rifampin-resistant and multi-drugresistant tuberculosis bacteria, ${ }^{19}$

Optimizing lead molecules from thiazolidinediones to thiazolidinones in Figure 1 by optimizing one of the ketone groups in the lead molecule may have good antidiabetic activity with reduced adverse effects. ${ }^{20}$ derivatives of Thiazolidine with a carbonyl group at the 4-position are thiazolidinone.

Substituents in the 2-, 3-, and 5-positions give the greatest difference in structure and properties exerted by the group attached to the carbon atom in the 2-position, ${ }^{21}$ the substituents attached to the nitrogen atom and Methylene are possible variations for the structures. ${ }^{22}$ The thiazolidinone ring system represents a privileged structure in drug discovery. Many bioactive compounds containing this ring system are so vast that the complete range of their biological activities can hardly be classified. ${ }^{23}$ The nucleus contains the following therapeutic importance in Figure 2. The present study is focusing on different ofloxacin-thiazolidinone derivatives its characterization and application of antitubercular activity and docking studies. 


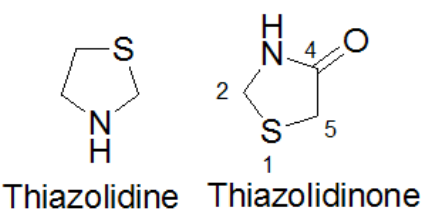

Figure 1: Nomenclature and naming.

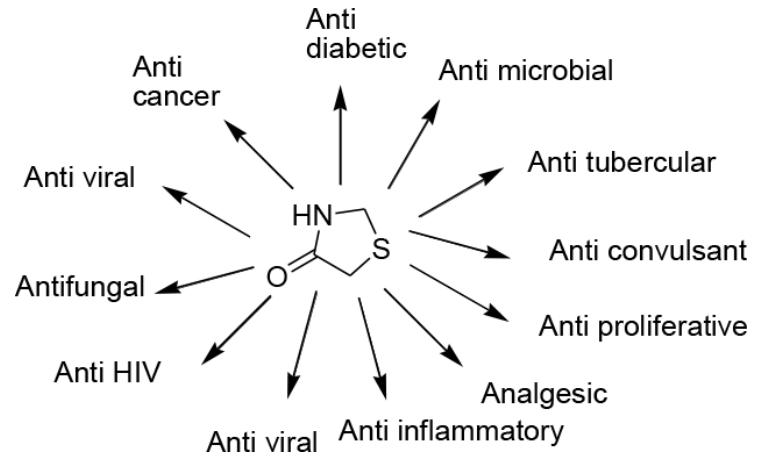

Figure 2: Therapeutic importance of thiazolidinone.

\section{MATERIALS AND METHODS}

Thioglycolic acid was purchased from Molychem and Hydrazine hydrate and other chemicals were purchased from SD FINE Chemicals, Hyderabad, India. All the other chemicals are of AR grade, chromatography is an essential analytical technique. For each of the compounds, the $\mathrm{R}_{\mathrm{f}}$ value is the unique characteristic parameter. Spectral studies have been performed like IR spectroscopy, ${ }^{1} \mathrm{H}-\mathrm{NMR}$ spectroscopy, High-resolution Mass spectrometry. All synthesized derivatives are soluble in chloroform and isopropanol.

\section{Synthesis of ofloxacin thiazolidinone derivatives}

The procedure consists of three steps.

\section{Step-1: Synthesis of Ofloxacin hydrazide}

The ofloxacin $(0.1 \mathrm{~mol})$ was ground with hydrazine hydrate $(80 \% 0.1 \mathrm{~mol})$ by mortar and pestle for 3-5 min and left for digestion for (10 $\mathrm{min}$ ) when the reaction mixture set into a solid mass. A thin layer of chromatography checked the completion of the reaction. The solid mass was crystallized using ethanol to give hydrazides.

\section{Step-2: Synthesis of Schiff bases}

To the above mixture of ofloxacin hydrazide $(0.01 \mathrm{~mol})$ and various aryl aldehyde $(0.01 \mathrm{~mol})$ in $20 \mathrm{ml}$ water was added three drops of concentrated Hydrochloric acid with continuous stirring for one hour at room temperature and insoluble solid was generated and washed with water, after drying pure solid was obtained and recrystallized from ethanol.

\section{Step-3: Synthesis of thiazolidinone}

0.02 mole of substituted Schiff base and 0.04 mole of thioglycolic acid with the presence of zinc chloride by taking the $30 \mathrm{mlN}, \mathrm{N}$-dimethylformamide as a solvent. The reaction was continuously refluxed for $5 \mathrm{hr}$. After the completion of the reaction, then cool the mixture, wash with ice-cold water and filter the mixture. solid was precipitated, filter then dried and recrystallized from hot ethanol.
In vitro Antitubercular activity by microplate Alamar Blue assay (MABA) method Procedure

The anti-TB activity of compounds was assessed against Mycobacterium tuberculosis using the microplate Alamar Blue assay method. This method is nontoxic using a thermally stable reagent and gives a good correlation with proportional and BACTEC radiometric methods. If say $200 \mu \mathrm{l}$ of sterile water was added to all outer perimeter wells of sterile 96 wells plate to minimize medium evaporation in the test well during incubation. to the 96 wells plated received $100 \mu \mathrm{l}$ of the 'Middlebrook $7 \mathrm{H} 9$ broth' and a serial dilution was made directly on the plate. The final drug concentration was made, tested 100 to $0.8 \mu \mathrm{g} / \mathrm{ml}$. Plates were sealed and incubated at $37^{\circ} \mathrm{C}$ for 5 days. After that $25 \mu$ of prepared $1: 1$ mixture of Alamar blue reagent and 10\% tween 80 was added to the plate and incubated for $24 \mathrm{hr}$. A blue colour was indicated as no bacterial growth, and a pink colour was indicated as bacterial growth. The MIC was the lowest drug concentration, which prevent the colour change from blue to pink. ${ }^{24,25}$ The standard strain used for Mycobacterium tuberculosis is H37 RV strain, Standard values for the Anti-TB test, which was performed. Isoniazid - $1.6 \mu \mathrm{g} / \mathrm{ml}$, Ethambutol - $1.6 \mu \mathrm{g} / \mathrm{ml}$, Pyrazinamide- $3.125 \mu \mathrm{g} / \mathrm{ml}$ Rifampicin - $0.8 \mu \mathrm{g} / \mathrm{ml}$, Streptomycin- $0.8 \mu \mathrm{g} / \mathrm{ml}$

\section{Docking studies}

Docking was performed by using Autodock vina freeware, ofloxacin derivatives act by inhibiting the enzyme DNA gyrase or Topoisomerase II of Mycobacterium tuberculosis, the selected protein target is PDB id 5BS8. This protein is a crystal structure of the topoisomerase II complex.

\section{RESULTS}

Various new derivatives were prepared, all the compounds obtained with good percentage yield ranging from $85-92 \%$, the synthesized compounds were observed by performing TLC, $\mathrm{R}_{\mathrm{f}}$ values were calculated, The solvent system or mobile phase to carry out TLC analysis was prepared by mixing n-hexane: Ethyl acetate (8:2). Physicochemical data is given in Table 1, spectral data is given below and structures are given in Table 2 and photographs of antitubercular activity are given in Figure 3 and results of antitubercular action are given in Table 3 and binding energy values are given in Table 4 .

\section{Spectral data of newly synthesized compounds}

IR $626 \mathrm{~cm}^{-1}$ (C-S), $798 \mathrm{~cm}^{-1}$ (C-F), $978 \mathrm{~cm}^{-1}$ (N-H) $2^{0}$ amine, 1476 $\mathrm{cm}^{-1}$ (C-C) Aromatic, $1700 \mathrm{~cm}^{-1}(\mathrm{C}=\mathrm{O})$ Carbonyls, 3028-3073 $\mathrm{cm}^{-1}$

\section{Table 1: Physico-chemical data of new compounds.}

\begin{tabular}{|c|c|c|c|c|c|}
\hline Sample code & Mol. Formula & $\begin{array}{c}\text { Mol. } \\
\text { Weight }\end{array}$ & $\begin{array}{c}\text { Melting } \\
\text { point }\end{array}$ & $\begin{array}{c}R_{f} \\
\text { value: }\end{array}$ & $\begin{array}{l}\% \\
\text { Yield: }\end{array}$ \\
\hline $\begin{array}{c}\mathrm{T} 1 \\
\text { (benzaldehyde) }\end{array}$ & $\mathrm{C}_{27} \mathrm{H}_{28} \mathrm{FN}_{5} \mathrm{O}_{4} \mathrm{~S}$ & 537.61 & $\begin{array}{l}110- \\
115^{\circ} \mathrm{C}\end{array}$ & 0.35 & $90 \%$ \\
\hline $\begin{array}{c}\text { T2 } \\
\text { (salicylaldehyde) }\end{array}$ & $\mathrm{C}_{27} \mathrm{H}_{28} \mathrm{FN}_{5} \mathrm{O}_{5} \mathrm{~S}$ & 553.61 & $\begin{array}{l}116- \\
120^{\circ} \mathrm{C}\end{array}$ & 0.25 & $92 \%$ \\
\hline $\begin{array}{c}\text { T3(chloro } \\
\text { benzaldehyde) }\end{array}$ & $\mathrm{C}_{27} \mathrm{H}_{27} \mathrm{ClFN}_{5} \mathrm{O}_{4} \mathrm{~S}$ & 572.05 & $\begin{array}{l}112- \\
115^{\circ} \mathrm{C}\end{array}$ & 0.45 & $91 \%$ \\
\hline T4(vanillin) & $\mathrm{C}_{28} \mathrm{H}_{30} \mathrm{FN}_{5} \mathrm{O}_{6} \mathrm{~S}$ & 583.63 & $\begin{array}{l}125- \\
130^{\circ} \mathrm{C}\end{array}$ & 0.31 & $94 \%$ \\
\hline $\begin{array}{c}\text { T5 } \\
\text { (cinnamaldehyde) }\end{array}$ & $\mathrm{C}_{29} \mathrm{H}_{30} \mathrm{FN}_{5} \mathrm{O}_{4} \mathrm{~S}$ & 563.64 & $\begin{array}{l}122- \\
125^{\circ} \mathrm{C}\end{array}$ & 0.38 & $85 \%$ \\
\hline $\begin{array}{c}\text { T6 } \\
\text { (furfuraldehyde) }\end{array}$ & $\mathrm{C}_{25} \mathrm{H}_{26} \mathrm{FN}_{5} \mathrm{O}_{5} \mathrm{~S}$ & 527.57 & $\begin{array}{l}132- \\
125^{\circ} \mathrm{C}\end{array}$ & 0.55 & $90 \%$ \\
\hline
\end{tabular}


Table 2: The codes and structures of synthesized compounds are.
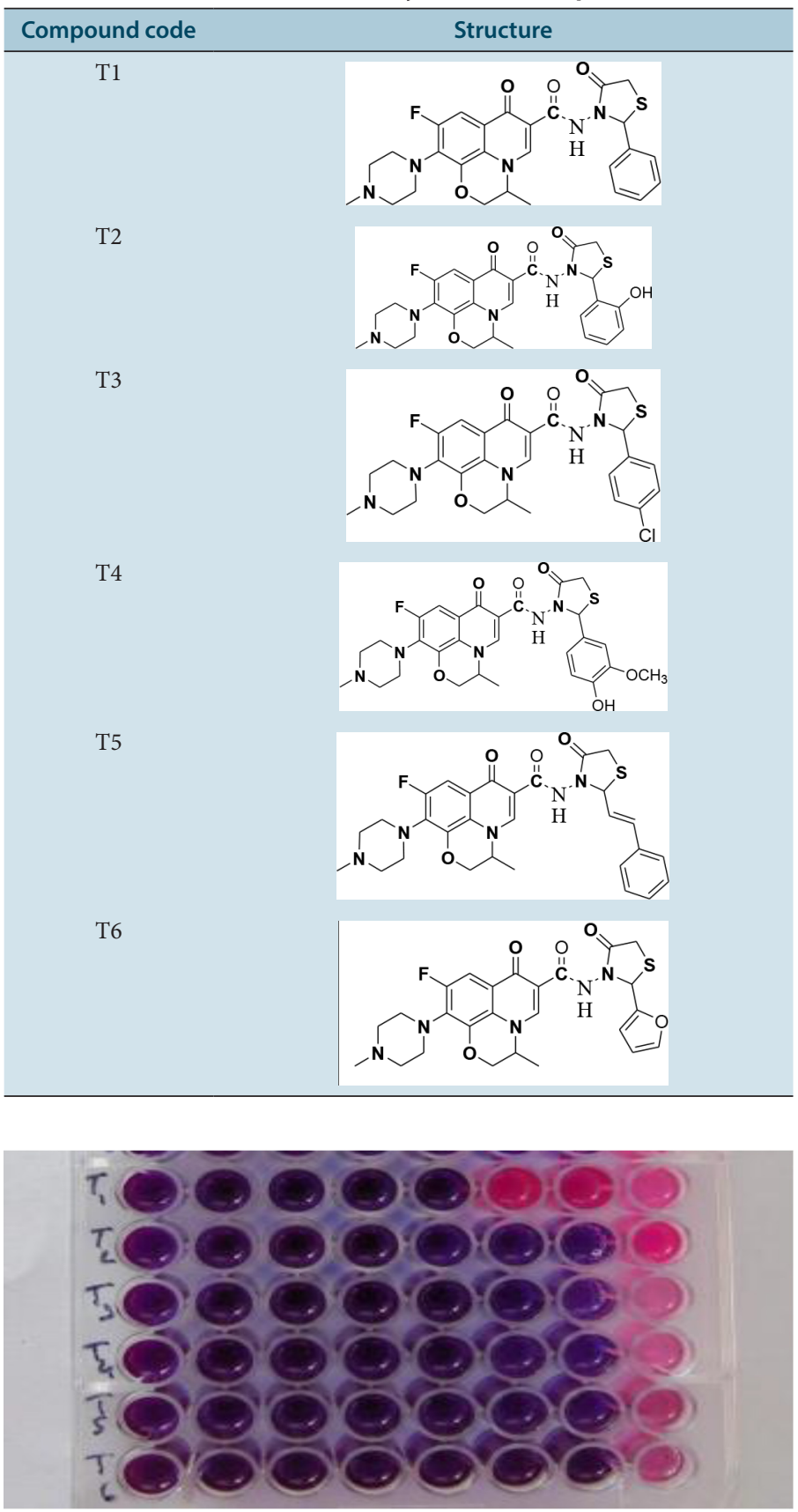

Figure 3: Photograph of Anti-tubercular activity of synthesized drugs.

Table 3: Results of Anti-tubercular activity.

\begin{tabular}{|c|c|c|c|c|c|c|c|c|c|}
\hline $\begin{array}{l}\dot{0} \\
\dot{n}\end{array}$ & $\begin{array}{l}\frac{0}{0} \\
\frac{\varepsilon}{\pi} \\
\text { ज }\end{array}$ & 을 & ㅇํ $\frac{\bar{\xi}}{\text { છे }}$ & ฝ & 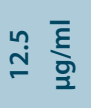 & ஸै & $\frac{\mathfrak{c}}{\stackrel{\bar{g}}{\mathrm{~m}}}$ & $\stackrel{\circ}{-} \frac{\bar{\varepsilon}}{\bar{g}}$ & $\stackrel{\infty}{\circ} \overline{\frac{\xi}{0}}$ \\
\hline 01 & $\mathrm{~T} 1$ & S & S & $S$ & $S$ & $S$ & $\mathrm{R}$ & $\mathrm{R}$ & $\mathrm{R}$ \\
\hline 02 & $\mathrm{~T} 2$ & $S$ & $S$ & S & $S$ & $S$ & S & S & $\mathrm{R}$ \\
\hline 03 & T3 & $S$ & $S$ & $S$ & $S$ & S & $S$ & $S$ & $\mathrm{R}$ \\
\hline 04 & $\mathrm{~T} 4$ & $S$ & $S$ & $S$ & $S$ & $S$ & $S$ & $S$ & $\mathrm{R}$ \\
\hline 05 & T5 & $S$ & $S$ & $S$ & $S$ & $S$ & S & $S$ & $\mathrm{R}$ \\
\hline 06 & T6 & S & S & S & $S$ & $S$ & $S$ & $S$ & $\mathrm{R}$ \\
\hline
\end{tabular}

NOTE

S - Sensitive R- Resistant
Table 4: Binding energy values of synthesized compounds.

\begin{tabular}{cc}
\hline Compound code & Binding energy $(\mathrm{Kcal} / \mathrm{mol})$ \\
\hline T1 & -10.5 \\
T2 & -10.5 \\
T3 & -10.7 \\
T4 & -10.6 \\
T5 & -10.7 \\
T6 & -10.1 \\
Ofloxacin standard & -9.0 \\
\hline
\end{tabular}

(C-H) alkene, $3118 \mathrm{~cm}^{-1}(\mathrm{C}-\mathrm{H})$ aromatic, $3388 \mathrm{~cm}^{-1}(\mathrm{~N}-\mathrm{H}) 2^{0}$ amine, ${ }^{1} \mathrm{H}-\mathrm{NMR}\left(400 \mathrm{MHz}, \mathrm{CDCl}_{3}\right) \delta 1.43\left(3 \mathrm{H}, \mathrm{d}\right.$, methyl), $2.49\left(3 \mathrm{H}, \mathrm{s}, \mathrm{N}-\mathrm{CH}_{3}\right)$, $2.72(4 \mathrm{H}, \mathrm{t}$, piperazine), $3.17(1 \mathrm{H}, \mathrm{m}) 3.35(4 \mathrm{H}, \mathrm{m}$,piperazine $) 3.38$ $(2 \mathrm{H}, \mathrm{s}$, thiazolidone $), 4.28(2 \mathrm{H}, \mathrm{d}), 5.92(1 \mathrm{H}, \mathrm{s}$, thiazolidinone $), 6.68(1 \mathrm{H}, \mathrm{s})$, $7.95(1 \mathrm{H}, \mathrm{s}), 7.10(5 \mathrm{H}, \mathrm{m}$, aromatic $), 8.0(1 \mathrm{H}, \mathrm{s}$, amide $)$, HRMS m/z $538.19, ; \mathrm{T} 1$

IR $631 \mathrm{~cm}^{-1}(\mathrm{C}-\mathrm{S}), 801 \mathrm{~cm}^{-1}(\mathrm{C}-\mathrm{F}), 978 \mathrm{~cm}^{-1}(\mathrm{~N}-\mathrm{H}) 2^{0}$ amine, $1542 \mathrm{~cm}^{-1}$ (C-C) Aromatic, $1703 \mathrm{~cm}^{-1}(\mathrm{C}=\mathrm{O})$ Carbonyls, $2980 \mathrm{~cm}^{-1}(\mathrm{C}-\mathrm{H})$ alkene, $3406 \mathrm{~cm}^{-1}(\mathrm{C}-\mathrm{H})$ aromatic, $3518 \mathrm{~cm}^{-1}(\mathrm{~N}-\mathrm{H}) 2^{0}$ amine, $3649 \mathrm{~cm}^{-1}(\mathrm{O}-\mathrm{H})$, ${ }^{1} \mathrm{H}-\mathrm{NMR}\left(400 \mathrm{MHz}, \mathrm{CDCl}_{3}\right) \delta 1.45$ (3H,d, methyl), $2.50(3 \mathrm{H}, \mathrm{s}$, $\left.\mathrm{N}-\mathrm{CH}_{3}\right), 2.72$ (4H,t,piperazine), $3.16(1 \mathrm{H}, \mathrm{m}) 3.34(4 \mathrm{H}, \mathrm{m}$, piperazine), $3.38(2 \mathrm{H}, \mathrm{s}$, thiazolidone $), 4.28(2 \mathrm{H}, \mathrm{d}), 5.0(1 \mathrm{H}, \mathrm{s}, \mathrm{OH}), 5.92(1 \mathrm{H}, \mathrm{s}$, thiazolidone), $6.68(1 \mathrm{H}, \mathrm{s}), 7.95(1 \mathrm{H}, \mathrm{s}), 7.10(4 \mathrm{H}, \mathrm{m}$, aromatic $), 8.0(1 \mathrm{H}, \mathrm{s}$, amide), HRMS m/z 554.25 ;T2

IR $659 \mathrm{~cm}^{-1}$ (C-S), $615 \mathrm{~cm}^{-1}$ (C-Cl), $702 \mathrm{~cm}^{-1}(\mathrm{C}-\mathrm{F}), 849 \mathrm{~cm}^{-1}(\mathrm{~N}-\mathrm{H}) 2^{0}$ amine, $1578 \mathrm{~cm}^{-1}$ (C-C) Aromatic, $1620 \mathrm{~cm}^{-1}(\mathrm{C}=\mathrm{O})$ Carbonyls, $3072 \mathrm{~cm}^{-1}$ $(\mathrm{C}-\mathrm{H})$ alkene, $3389 \mathrm{~cm}^{-1}(\mathrm{C}-\mathrm{H})$ aromatic, $3436 \mathrm{~cm}^{-1}(\mathrm{~N}-\mathrm{H}) 2^{0}$ amine, ${ }^{1} \mathrm{H}-\mathrm{NMR}\left(400 \mathrm{MHz}, \mathrm{CDCl}_{3}\right) \delta 1.42\left(3 \mathrm{H}, \mathrm{d}\right.$,methyl), $2.49\left(3 \mathrm{H}, \mathrm{s}, \mathrm{N}-\mathrm{CH}_{3}\right)$, $2.71(4 \mathrm{H}, \mathrm{t}$, piperazine $), \quad 3.17(1 \mathrm{H}, \mathrm{m}), \quad 3.35(4 \mathrm{H}, \mathrm{m}$,piperazine $), \quad 3.38$ (2H,s,thiazolidone), $4.28(2 \mathrm{H}, \mathrm{d}), 5.92(1 \mathrm{H}, \mathrm{s}$, thiazolidinone), $6.68(1 \mathrm{H}, \mathrm{s})$, $7.96(1 \mathrm{H}, \mathrm{s}), 7.10(4 \mathrm{H}, \mathrm{m}$, aromatic), 8.0 $(1 \mathrm{H}, \mathrm{s}$, amide), HRMS m/z $573.63 ; \mathrm{T} 3$

IR $799 \mathrm{~cm}^{-1}(\mathrm{C}-\mathrm{Cl}), 857 \mathrm{~cm}^{-1}(\mathrm{~N}-\mathrm{H}) 2^{0}$ amine, $1525 \mathrm{~cm}^{-1}$ (C-C) Aromatic, $1688,1602 \mathrm{~cm}^{-1}(\mathrm{C}=\mathrm{O})$ Carbonyls, $3449 \mathrm{~cm}^{-1}(\mathrm{C}-\mathrm{H})$ alkene, $2555 \mathrm{~cm}^{-1}(\mathrm{C}-\mathrm{H})$ aromatic, $3724 \mathrm{~cm}^{-1}(\mathrm{~N}-\mathrm{H}) 2^{0}$ amine, $3852 \mathrm{~cm}^{-1}(\mathrm{O}-\mathrm{H})$ ${ }^{1} \mathrm{H}-\mathrm{NMR}\left(400 \mathrm{MHz}, \mathrm{CDCl}_{3}\right) \delta 1.43\left(3 \mathrm{H}, \mathrm{d}\right.$,methyl), $2.49\left(3 \mathrm{H}, \mathrm{s}, \mathrm{N}-\mathrm{CH}_{3}\right)$, 2.72 (4H,t,piperazine), $3.16(1 \mathrm{H}, \mathrm{s}) 3.34(4 \mathrm{H}, \mathrm{m}$, piperazine $), 3.38$ (2H,s,thiazolidone), $3.75(3 \mathrm{H}, \mathrm{s}), 4.28(2 \mathrm{H}, \mathrm{d}), 5.0(1 \mathrm{H}, \mathrm{s}, \mathrm{OH}), 5.92$ $(1 \mathrm{H}, \mathrm{s}$, thiazolidone), $6.68(1 \mathrm{H}, \mathrm{s}), 7.95(1 \mathrm{H}, \mathrm{s}), 7.10(3 \mathrm{H}, \mathrm{m}$, aromatic), 8.0(1H,s, amide), HRMS m/z 584.67; T4

IR $697 \mathrm{~cm}^{-1}(\mathrm{C}-\mathrm{S}), 627 \mathrm{~cm}^{-1}(\mathrm{C}-\mathrm{F}), 1391 \mathrm{~cm}^{-1}(\mathrm{~N}-\mathrm{H}) 2^{0}$ amine, $1461 \mathrm{~cm}^{-1}$ (C-C) Aromatic, $1563 \mathrm{~cm}^{-1}(\mathrm{C}=\mathrm{O})$ Carbonyls, $2918 \mathrm{~cm}^{-1}(\mathrm{C}-\mathrm{H})$ alkene, $3386 \mathrm{~cm}^{-1}(\mathrm{C}-\mathrm{H})$ aromatic, $3457 \mathrm{~cm}^{-1}(\mathrm{~N}-\mathrm{H}) 2^{0}$ amine, ${ }^{1} \mathrm{H}-\mathrm{NMR}(400 \mathrm{MHz}$, $\left.\mathrm{CDCl}_{3}\right) \delta 1.43\left(3 \mathrm{H}, \mathrm{d}\right.$,methyl), $2.49\left(3 \mathrm{H}, \mathrm{s}, \mathrm{N}-\mathrm{CH}_{3}\right), 2.71$ (4H,t,piperazine), 3.16( $1 \mathrm{H}, \mathrm{s}), 3.34$ (4H,m,piperazine), $3.38(2 \mathrm{H}, \mathrm{s}$, thiazolidone), $4.28(2 \mathrm{H}, \mathrm{d})$, $5.92(1 \mathrm{H}, \mathrm{s}$, thiazolidone), $6.20(1 \mathrm{H}, \mathrm{m}), 6.58(1 \mathrm{H}, \mathrm{d}$, alkene) $6.68(1 \mathrm{H}, \mathrm{s})$, $7.96(1 \mathrm{H}, \mathrm{s}), 7.10(5 \mathrm{H}, \mathrm{m}$, aromatic $), 8.0(1 \mathrm{H}, \mathrm{s}$, amide $)$, HRMS m/z $566.31 ; \mathrm{T} 5$

IR $659 \mathrm{~cm}^{-1}(\mathrm{C}-\mathrm{S}), 628 \mathrm{~cm}^{-1}$ (C-F), $742 \mathrm{~cm}^{-1}(\mathrm{~N}-\mathrm{H}) 2^{0}$ amine, $1476 \mathrm{~cm}^{-1}$ (C-C) Aromatic, $1576 \mathrm{~cm}^{-1}(\mathrm{C}=\mathrm{O})$ Carbonyls, $2933 \mathrm{~cm}^{-1}(\mathrm{C}-\mathrm{H})$ alkene, $3031 \mathrm{~cm}^{-1}(\mathrm{C}-\mathrm{H})$ aromatic, $3369 \mathrm{~cm}^{-1}(\mathrm{~N}-\mathrm{H}) 2^{0}$ amine, ${ }^{1} \mathrm{H}-\mathrm{NMR}(400 \mathrm{MHz}$, $\left.\mathrm{CDCl}_{3}\right) \delta 1.44\left(3 \mathrm{H}, \mathrm{d}\right.$,methyl), $2.49\left(3 \mathrm{H}, \mathrm{s}, \mathrm{N}-\mathrm{CH}_{3}\right), 2.72(4 \mathrm{H}, \mathrm{t}$, piperazine), $3.17(1 \mathrm{H}, \mathrm{m}), 3.35(4 \mathrm{H}, \mathrm{m}$, piperazine), 3.38 (2H,s,thiazolidone), 4.28 $(2 \mathrm{H}, \mathrm{d}), 5.92(1 \mathrm{H}, \mathrm{s}$, thiazolidone $), 6.68(1 \mathrm{H}, \mathrm{s}), 7.96(1 \mathrm{H}, \mathrm{s}), 6-7.3(3 \mathrm{H}, \mathrm{m}$, furan), 8.0(1H,s, amide), HRMS m/z 530.24; T6 


\section{DISCUSSION}

Ofloxacin is a starting material for the synthesis of several compounds. Ofloxacin is treated with equimolar concentration of hydrazine hydrates and then treated with different aldehydes gives Schiff bases then further reacting gives ofloxacin thiazolidinones derivatives in Scheme 1. All the compounds were confirmed by TLC using silica gel pre-coated aluminium sheet, Melting points were tested using melting point apparatus (open capillary tube), solubility tested using different solvents and spectral methods like FTIR spectra has recorded using Bruker instrument and analysed the functional groups, the ${ }^{1} \mathrm{H}-\mathrm{NMR}$ nucleus is $1 \mathrm{H}$, a solvent used is $\mathrm{CDCl}_{3}$, Bruker Avance $400 \mathrm{MHz}$ instrument used to analyse the number of protons, a chemical shift was recorded in $\delta$ ppm, TMS as standard and HRMS is a sophisticated instrument used to find the molecular mass. Physicochemical data has been analysed. ${ }^{26}$ The compounds were evaluated in vitro antitubercular action using the MABA method and compared with standard Isoniazid, Rifampicin, and Streptomycin Ethambutol, Pyrazinamide drugs. ${ }^{27}$ All compounds were showing good results at concentrations $1.6 \mu \mathrm{g} / \mathrm{ml}$. S means sensitive and $\mathrm{R}$ means resistance, five compounds are sensitive towards antitubercular action at $1.6 \mu \mathrm{g} / \mathrm{ml}$ (T2-T6 drugs) are equipotent. one compound T1 showed activity at a concentration of $6.25 \mu \mathrm{g} / \mathrm{ml}$. the antitubercular action in the photograph indicating that blue colour is active (sensitive) and pink colour inactive. ${ }^{28,29}$ Molecular Docking studies reveal that all ligands showed good binding interactions and the energy values are more than the standard of ofloxacin. Mycobacterium tuberculosis bacteria contain DNA Gyrase or Topoisomerase II enzyme is responsible for ofloxacin activity and the crystal structure of mycobacterium tuberculosis protein 5BS8 is downloaded from the protein data bank and has resolution $2.4 \mathrm{~A}^{0}$. (For better results, resolution of protein should be less than $2.5 \mathrm{~A}^{0}$ ) Docking was performed using auto dock vina. it is an academic free version of the software, the advantage of Autodock vina is stability, whenever we repeat docking, we get the same values when compared to Auto dock 4.2., in which the values are unstable. For ligand preparation, The ligands were drawn using chem sketch, chem draw tools. Energy minimization was done for molecules in chimera 1.14 saved in ".pdb" format. Four files used for docking: preparation of ligand ".pdbqt" file, preparation of macromolecule ".pdbqt" file, grid parameter file “.gpf”. Docking parameter file “.dpf”.A grid map was created with a

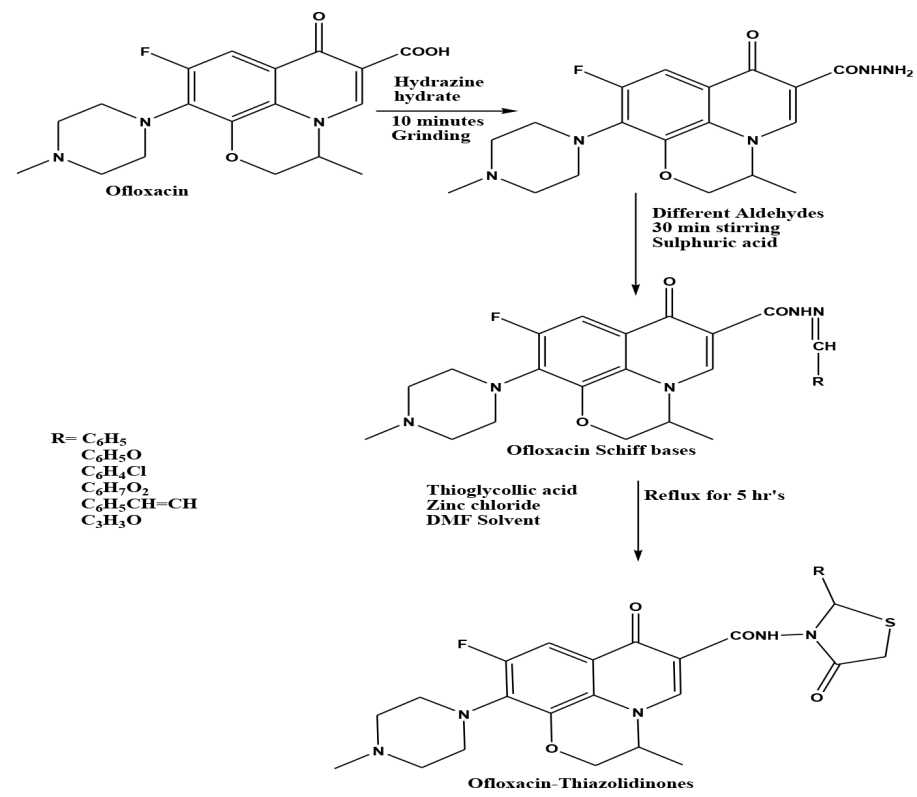

Scheme 1: Synthesis of ofloxacin thiazolidinones. 3-dimensional lattice. The docking results were displayed in the "dlg". The protein 5BS8 and different ligands (6 compounds) interaction has been done by docking and can be viewed by visualization tools. All Structures drawn from ChemDraw tools saved as pdb or mol format, protein is a macromolecule for preparation of macromolecule we have to remove water molecules and hetero atoms then add polar hydrogens and saved as pdb or mol format Pyrx is software used to load molecules. docking studies performed using Autodock vina free software, The protein $5 \mathrm{BS} 8$ is docked with different ligands and the interaction can be viewed by visualization tools like discovery studio. In protein-ligand interactions all compounds showed good docking results above the standard value, Among T3, T5 represented in 2D structure interacting with protein 5BS8 given in Figure 4 and Figure 5. The hydrogen bonds are formed interacting with 8 amino acids showing docking results at -10.7, depicting the docking poses and molecular interactions responsible for binding. Bond lengths are measured in angstrom units. The binding or docked energy should be minimum considered as the best ligands. This molecular docking helped in lead optimization and lead generation of highly potent compounds. Docking studies reveal that compounds T1-T6 has more binding affinity towards protein 5BS8 and has a more binding relationship with a receptor. This study showed that ligands might have high anti-tubercular activity properties and are future potent antitubercular drugs.

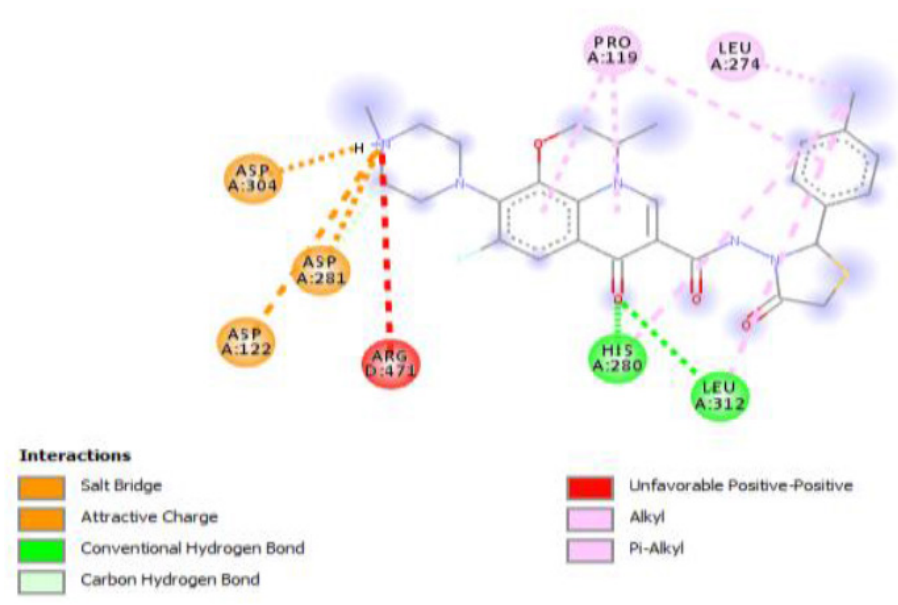

Figure 4: $2 \mathrm{D}$ interactions of protein $5 \mathrm{bs} 8$ and $\mathrm{T} 3$.

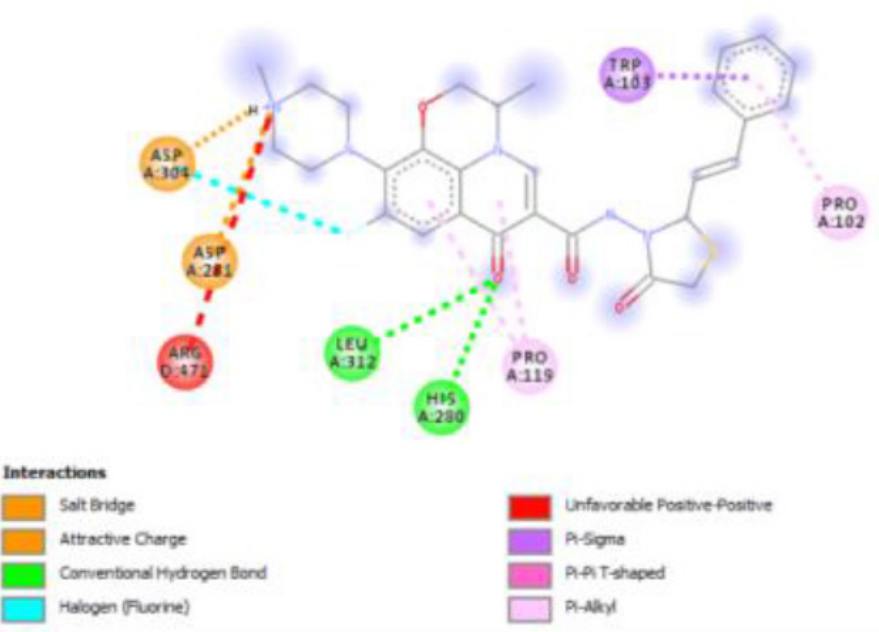

Figure 5: 2D interactions of protein $5 \mathrm{bs} 8$ and T5. 


\section{CONCLUSION}

Ofloxacin containing thiazolidinone derivatives were synthesized and investigated for their antitubercular action by the 'Microplate Alamar Blue Assay' method. Further synthesis work can be extended on products of ofloxacin. After comparing the antitubercular action of ofloxacin derivatives, their minimum inhibitory concentration values were found to be significant. Docking studies also supported, The beneficial effects of these drugs reveals a great promise for the use of ofloxacinthiazolidinone derivatives.

\section{ACKNOWLEDGEMENT}

We are thankful to VIT-SIF, Vellore for NMR and MASS spectra and thankful to students and management for the completion of this article and thankful to Darwin laboratories, Anantapur for providing ofloxacin as a gift sample.

\section{CONFLICT OF INTEREST}

The authors declare that there is no conflict of interest

\section{REFERENCES}

1. Godge RK, Kunkulol R. Synthesis of novel heterocyclic quinolone compound for anti -tubercular activity. IJCBR. 2018:44-9. doi: 10.31878/ijcbr.2018.43.10.

2. Sharma PC, Jain A, Yar MS, Pahwa R, Singh J, Chanalia P. Novel fluoroquinolone derivatives bearing $\mathrm{N}$-thiomide linkage with 6-substituted-2aminobenzothiazoles: Synthesis and antibacterial evaluation. Arab J Chem. 2017; 10:S568-75. doi: 10.1016/j.arabjc.2012.11.002.

3. Goyal R, Sharma A, Thakur VK, Ola M, Sharma PC. Green chemistry approaches towards the design and synthesis of anti-infective fluoroquinolone derivatives. Current Research in Green and Sustainable Chemistry. 2021;4. doi: 10.1016/j. crgsc.2020.100044, PMID 100044

4. Chander Sharma P, Piplani M, Rajak H. An insight into patents of fluoroquinolone derivatives. Lett Drug Des Discov. 2015;12(10):844-55. doi: 10.2174/157018081 2666150429234635

5. Abdullah FM, Singh AK. Synthesis, characterization and pharmacological studies of some substituted fluoroquinolones. Orientjchem. 2013;29(2):609-15. doi: $10.13005 /$ ojc/290231.

6. Alam MS, Rahman SMM, Lee D. Synthesis, biological evaluation, quantitativeSAR and docking studies of novel chalcone derivatives as antibacterial and antioxidant agents. Chemical Papers. 2015;69(8). doi: 10.1515/ chempap-2015-0113.

7. Pranger AD, Van der Werf TS, Kosterink JGW, Alffenaar JWC. The role of fluoroquinolones in the treatment of tuberculosis in 2019. Drugs. 2019;79(2):161-71. doi: 10.1007/s40265-018-1043-y.

8. Sharma PC, Kumar R, Chaudhary M, Sharma A, Rajak H. Synthesis and biological evaluation of novel benzothiazole clubbed fluoroquinolone derivatives. J Enzyme Inhib Med Chem. 2013;28(1):1-10. doi: 10.3109/14756366.2011.611943.

9. Patel NB, Patel SD. Synthesis and antimicrobial study of fluoroquinolone-based 4-thiazolidinones. Med Chem Res. 2010;19(8):757-70. doi: 10.1007/s00044-009 9228-2.

10. Kumar $V$, Kumar $A$. Synthesis and antimicrobial activity of thiazolidinone norfloxacin hybrids. Indian J Chem. 2011;50B:1496-503.

11. Sultana N. Synthesis, characterization and biological evaluation of a series of levofloxacin carboxamide analogues. Bull Korean Chem Soc. 2009;30(10):2294-8. doi: 10.5012/bkcs.2009.30.10.2294.

12. Huang $X$, Chen D, Wu N, Zhang A, Jia Z, Li X. The synthesis and biological evaluation of a novel series of $\mathrm{C} 7$ non-basic substituted fluoroquinolones as antibacterial agents. Bioorganic and Medicinal Chemistry Letters.
2009;19(15):4130-3. doi: 10.1016/j.bmcl.2009.06.006.

13. Jakhar K, Makrandi JK. ChemInform abstract: An efficient synthesis of 3-Bromoflavones (II) under Solvent Free Conditions Using Grinding Technique. ChemInform. 2012;43(38):no-no. doi: 10.1002/chin.201238132.

14. Rajalakshmi R, Santhi R, Elakkiya T. Synthesis, characterization, biological evaluation and MolecularDocking studies of some Oxazinyl-Thiazolidinone derivatives. Asian J Chem. 2020;32(9):2125-9. doi: 10.14233/ajchem.2020.22710.

15. Ravichandran V, Jain A, Kumar KS, Rajak H, Agrawal RK. Design, synthesis, and evaluation of thiazolidinone derivatives as antimicrobial and anti-viral agents. Chem Biol Drug Des. 2011;78(3):464-70. doi: 10.1111/j.1747-0285.2011.01149.x.

16. Kumar P, Duhan M, Kadyan K, Sindhu J, Kumar S, Sharma H. Synthesis of novel inhibitors of $\alpha$-amylase based on the thiazolidine-4-one skeleton containing a pyrazole moiety and their configurational studies. Med Chem Commun. 2017:8(7):1468-76. doi: 10.1039/C7MD00080D.

17. Naglah AM, Askar AA, Hassan AS, Khatab TK, Al-Omar MA, Bhat MA Biological evaluation and molecular docking with in silico physicochemical, pharmacokinetic and toxicity prediction of pyrazolo[1,5-a]pyrimidines. Molecules. 2020;25(6):1431. doi: 10.3390/molecules25061431.

18. Ofloxacin. React Wkly. 2015;1548;1:190-

19. Shih M, XuY, Yang Y, Lin G. A facile synthesis and antimicrobial activity evaluation of Sydnonyl-substituted thiazolidine derivatives. Molecules. 2015;20(4):6520-32. doi: 10.3390/molecules20046520

20. Neuenfeldt P, Drawanz B, Aguiar A, FigueiredoJr. F, Krettli A, Cunico W Multicomponent Synthesis of New Primaquine Thiazolidinone Derivatives. Synthesis. 2011;2011(23):3866-70. doi: 10.1055/s-0031-1289580.

21. Garg A, Garg S. 1,3,4-Thiadiazole Attached 2,3-disubstituted Thiazolidinones Derivatives: Synthesis and Biological Evaluation. Indian J Pharm Educ Res. 2021;55(4):1151-63. doi: 10.5530/ijper.55.4.215.

22. Taranalli A, Bhat A, Srinivas S, Saravanan E. Antiinflammatory, analgesic and antipyretic activity of certain thiazolidinones. Indian J Pharm Sci. 2008;70(2):159. doi: 10.4103/0250-474X.41448.

23. Prasad D, Kumar A, Shukla PK, Nath M. Design, synthesis and antimicrobial evaluation of novel 2-aryl-thiazolidin-4-one derivatives. Org Med Chem Lett. 2011;1(1). doi: 10.1186/2191-2858-1-4.

24. Mohammadhosseini N, Alipanahi Z, Alipour E, Emami S, Faramarzi MA Samadi N, et al. Synthesis and antibacterial activity of novel levofloxacin derivatives containing a substituted thienylethyl moiety. DARU J Pharm Sci. 2012;20(1). doi: 10.1186/2008-2231-20-16.

25. Chintakunta R, Gopireddy VS. Synthesis, characterization and evaluation of anti-tubercular activity of ofloxacin chalcone conjugates. JPRI. 2021:22-30. doi: 10.9734/jpri/2021/v33i1631292.

26. Dinakaran $M$, Senthilkumar $P$, Yogeeswari $P$, China $A$, Nagaraja $V$, Sriram D. Nove ofloxacin derivatives: Synthesis, antimycobacterial and toxicological evaluation. Bioorg Med Chem Lett. 2008;18(3):1229-36. doi: 10.1016/j.bmcl.2007.11.110.

27. Hajlaoui K, Guesmi A, Ben Hamadi N, Msaddek M. One-pot synthesis of new triazole-sucrose derivatives via click chemistry and evaluation of their antitubercular activity. Heterocycl Commun. 2016;22(4). doi: 10.1515/hc-2016-0028.

28. Arayne MS, Sultana N, Haroon U, Zuberi MH, Rizvi SBS. Synthesis, characterization and biological activity of a series of carboxamide derivatives of ofloxacin. Arch Pharm Res. 2010;33(12):1901-9. doi: 10.1007/s12272-010-1203-4

29. Lourenço MCS, Souza MVNd, Pinheiro AC, Ferreira MdL, Gonçalves RSB, Nogueira TCM, et al. Evaluation of anti-tubercular activity of nicotinic and isoniazid analogues. Arkivoc;2007(15):181-91. doi: 10.3998/ark.5550190.0008.f18. 